\title{
DETECTION OF POLLEN FLOW IN THE SEEDLING SEED ORCHARD OF Acacia mangium USING DNA MARKER
}

\author{
Vivi Yuskianti ${ }^{1}$ and Keiya Isoda ${ }^{2,3}$ \\ Received : 12 December 2012, Accepted : 28 June 2013
}

\begin{abstract}
Pollen pattern dispersal in seedling seed orchard (SSO) is an essential part of a tree-improvement program. Two SSOs of Acacia mangium in South Kalimantan and South Sumatra that represent similar resources in different environments were used in this study. Genotypes of all trees and seeds from a subset of 10 mother trees in each orchard were determined for 12 microsatellite loci, and parentage analysis was carried out. The results shows that the pollen dispersal pattern in both SSOs decrease with distance from mother tree. Patterns of pollen dispersal, dispersal distance and cumulative frequency of pollen dispersal distance were similar in both SSOs. Random pollen dispersal were found in both SSOs. About $80 \%$ of all crosses were found within a 40 -m distance range with the most frequent pollination distance between mother tree and male male parents was 0-10 m. No self-pollinated seed was detected. Application of all these aspects found in this study such as random pollen dispersal and the effective pollen dispersal distance can be useful for establishing seedling seed orchard, clonal seed orchard and in other tree improvement activities of $A$. mangium.
\end{abstract}

Keywords: Acacia mangium, seedling seed orchard, pollen dispersal, effective distance, selfing ratio

\section{INTRODUCTION}

Understanding the mating system and patterns of pollen dispersal in tree species is important for conservation and natural resource management as well as for successful breeding program and domestication (Millar et al., 2008). Mating system has been studying in Acacia species. Most of the studies found high levels of outcrossing in acacia species (Mandal and Ennos, 1995; Casiva et al., 2004; George et al., 2008; Millar et al., 2008) with a little differences of a mixed-mating system in $A$. sciophanes and $A$. anfractuosa (Coates et al., 2006). Study on mating system of $A$. mangium in natural populations showed that outcrossing rates in

${ }^{1}$ Center for Forest Biotechnology and Tree Improvement, Jl. Palagan Tentara Pelajar Km 15, Purwobinangun, 55582 Sleman, Yogyakarta, Indonesia

${ }^{2}$ JICA Forest Tree Improvement Project Phase II, Jl. Palagan Tentara Pelajar Km 15, Purwobinangun, 55582 Sleman, Yogyakarta, Indonesia

${ }^{3}$ Curent address: Kansai Regional Breeding Office, Forest Tree Breeding Center, Forestry and Forest Products Research Institute, 1043 Uetsukinaka, Syouohcho, Katutagun, Okayama 709-4335, Japan

"Corresponding Author:vivi_yuskianti@yahoo.com natural populations was ranged from complete selfing in outlying populations with low genetic diversity to complete outcrossing in the more variable New Guinea populations (Butcher et al., 2004).

Genetic studies of mating system have been conducted using isoenzyme (Mandal and Ennos, 1995; Casiva et al., 2004; Coantes et al., 2006 and George et al., 2006). Although population subdivision at isoenzyme loci can be used to estimate gene flow, it is difficult to determine the relative contributions of pollen movement and seed dispersal to overall migration rates (Dow and Ashley, 1996). Microsatellite markers are suitable for mating system studies as they are highly polymorphic, co-dominant, and considered to be selectively neutral (Tabbener and Cottrell, 2003; Millar et al., 2008). PCR-based microsatellite analysis is also quick, and requires only small amounts of DNA (Hancock, 1999; Glaubitz and Moran, 2000). Therefore, microsatellite markers have been widely used for investigating mating system, patterns of pollen dispersal, pollen donor composition and parentage of saplings in many species (Dow and Ashley, 1996; Tabbener and 
Cottrell, 2003; Robledo-Arnuncio and Gil, 2005; Millar et al., 2008; Hasegawa et al., 2009).

A comprehensive tree improvement program for tropical fast growing species in Indonesia was launched in early 1992's (Nirsatmanto, 2005). This program was intended to cover up some commercial species: $A$. mangium, $A$. crassicarpa, Eucalyptus pellita, E.urophylla, and Paraserianthes falcataria (Hashimoto et al., 1996). Among them, at present, $A$. mangium was the earliest progressed program with the improvement mainly subjected to meet the demand of supplying material for pulp and paper industry (Nirsatmanto, 2005). Through these programs, several seedling seed orchards (SSOs) of $A$. mangium have been established in several areas in Indonesia. The purpose of this study was to investigate the pattern of pollen dispersal in two seedling seed orchards (SSOs) i.e. AM006 group C (South Kalimantan) and AM004 group D (South Sumatra) in Indonesia. The results of this study can be used for evaluating and managing the existing seed orchards, designing the next SSOs, and also designing more efficient clonal seed orchards (CSOs) for improved seed production.

\section{MATERIAL AND METHOD}

\section{A. Study Site and Sample Collection}

Two first-generation (F1) seedling seed orchards (SSOs) in Indonesia and their offspring were used. One SSO is in South Kalimantan (AM006 Group C) and the other is in South Sumatra (AM004 Group D). AM006 Group C is located in Sebuhung village, sub-district of Lorong, district of Tanah Laut, South Kalimantan province, Kalimantan Island; AM004 Group D is located in Talang Ubi sub-district, district of Muara Enim, South Sumatra province, Sumatra Island (Table 1). These SSOs were selected because they represent similar resources in different environments and should provide an indication of consistency in the mating system in A. mangium.

More than 60 families from several Australian

Table 1. Detailed information about the two seedling seed orchards (SSO) used for the mating system study in $A$. mangium

\begin{tabular}{|c|c|c|}
\hline Information & South Kalimantan (AM006) SSO & South Sumatra (AM004) SSO \\
\hline Species & A. mangium $(\mathrm{C})$ & A. mangium $(\mathrm{D})$ \\
\hline Country & Australia & Australia \\
\hline Provenance & Claudie River, etc & Claudie River, etc \\
\hline Seed Sowing data & September 4, 1993 & September 29, 1993 \\
\hline Planting Date & December 23-24, 1993 & January 7-9, 1994 \\
\hline Spacing & $4 \times 2 \mathrm{~m}$ & $4 \times 2 \mathrm{~m}$ \\
\hline Ground cultivation & Plowing $2 \times$ & Plowing $1 \times$ \\
\hline Fertilizer & NPK 2 ×/year & TSP $1 \times$ and urea $1 \times$ \\
\hline Vegetation cover & Imperata cyclindrica & Imperata cylindrica \\
\hline \multicolumn{3}{|l|}{ Experimental site } \\
\hline Latitude & $3^{\prime} 58^{\prime}$ to $4^{\prime} 08^{\prime}$ South & 4' South \\
\hline Longitude & $114^{\prime} 37^{\prime}$ to $114^{\prime} 42^{\prime}$ East & 104' East \\
\hline Elevation & $15-150 \mathrm{~m}$ & $80 \mathrm{~m}$ \\
\hline Climate type & B (Schmidt and Ferguson) & A (Schmidt and Ferguson) \\
\hline Annual rainfall & $2730 \mathrm{~mm}$ & $2781.23 \mathrm{~mm}$ \\
\hline Max. temperature & $33^{\circ} \mathrm{C}$ & $33^{\circ} \mathrm{C}$ \\
\hline Min. temperature & $23^{\circ} \mathrm{C}$ & $24^{\circ} \mathrm{C}$ \\
\hline Wind speed & Middle & Low \\
\hline Slope & $0-15 \%$ & $5 \%$ \\
\hline Soil type & Ferralsols & Acrisols \\
\hline \multicolumn{3}{|l|}{ Site details } \\
\hline Compartment & Block HoD/Sebuhur & Block Setuntung II/Petak 37 \\
\hline Site Area & 2.00 ha & $0.96 \mathrm{ha}$ \\
\hline Design & RCBD & RCBD \\
\hline Number of trees/plot & 4 & 4 \\
\hline Number of families & 63 & 63 \\
\hline Number of replication & 10 & 8 \\
\hline
\end{tabular}


provenances has been used for development of F1 generation. Progeny test was conducted in both SSOs: AM006 Group C and AM004 Group D. Four trees per plot of each family were planted initially and within-plot selection was applied, after which only one tree per plot remained. All trees in each SSO were used to determine male parent genotypes; there were 379 trees in Group C AM006 South Kalimantan and 251 trees in AM004 South Sumatra.

All the material used in this study were collected in 2002. Two or three leaves from each tree from these orchards were collected and put in an envelope with sufficient proportion of silica gel inside. The silica gel was replaced many times to dry the leaves and minimize decay or associated fungi. For offspring, seeds were collected from ten mother trees (Butcher et al., 2004; Millar et al., 2008) at each site. The mother trees were selected based on their position in the orchard. These positions were expected to represent anticipated trends in the mating system in each orchard. From each mother tree, representative pods from throughout the crown were collected; twenty seeds were randomly selected from these bulky pods.

\section{B. DNA Extraction}

Genomic DNA from both leaves and seeds was isolated using a modified CTAB method (Shiraishi and Watanabe, 1995). The extraction procedure for each differed. For leaves, $100 \mathrm{mg}$ were cut into small pieces and ground to a powder under liquid nitrogen in a pestle and mortar. The powder was then put into a $2.0 \mathrm{ml}$ microtube and one $\mathrm{ml}$ of extraction buffer $(100 \mathrm{mM}$ Tris- $\mathrm{HCl} \mathrm{pH}$ 9.0, 1.4 M NaCl, 20 mM EDTA, 2\% CTAB, 0.5\% B-mercaptoethanol) added. For seeds, every fresh seed was put into a tea bag, boiled in water for 10 min, and the seed coat removed manually. The naked seed was placed in a $1.5 \mathrm{ml}$ microtube, incubated for $30 \mathrm{~min}$ at $65^{\circ} \mathrm{C}$ in $0.6 \mathrm{ml}$ extraction buffer (100 mM Tris- $\mathrm{HCl} \mathrm{pH} 9.0,1.4 \mathrm{M} \mathrm{NaCl}, 20$ mM EDTA, 2\% CTAB, 0.5\% ß-mercaptoethanol) and then ground using a pellet pestle. The ground material of both leaves and seeds was then incubated in their respective microtube at $65^{\circ} \mathrm{C}$ for $1 \mathrm{~h}$. Chloroform was used twice to wash the supernatant containing DNA. Sodium acetate and isopropanol were used to precipitate the DNA. A DNA pellet was made by centrifuging the tube at 15,000 rpm. The pellet was washed with $70 \%$ ethanol and then distilled water added to redissolve the DNA.

\section{PCR Analysis}

Twelve microsatellite markers (Butcher et al., 2000) were used for genotype analysis. For each marker, a fluorescent-labelled primer and a nonlabelled reverse primer were synthesized for PCR analysis. PCR analysis was carried out in a $10 \mu \mathrm{l}$ reaction containing 1 PCR buffer (Perkin-Elmer, Applied Biosystems, USA), 1.5 to $3.0 \mathrm{mM} \mathrm{MgCl}$, and 0 or $1 \%$ formamide (Table 2), $200 \mu \mathrm{M}$ each dNTP, $0.5 \mu \mathrm{M}$ each primer, 0.5 unit AmpliTaq Gold DNA polymerase (Perkin-Elmer, Applied Biosystems, USA), and 25 ng template DNA. The optimized $\mathrm{MgCl}_{2}$ concentration and the addition of formamide for each marker (Table 2) were used to obtain the minimum or maximum single nucleotide addition caused by the Taq DNA polymerase.

Amplification was performed in a GeneAmp PCR System 9700 (Perkin-Elmer, Applied Biosystems, USA) at $94^{\circ} \mathrm{C}$ for $10 \mathrm{~min}, 35$ cycles at $94^{\circ} \mathrm{C}$ for $30 \mathrm{~s}, 50-60^{\circ} \mathrm{C}$ for $30 \mathrm{~s}, 72^{\circ} \mathrm{C}$ for $60 \mathrm{~s}$, followed by $1 \mathrm{~min}$ at $72^{\circ} \mathrm{C}$ for the extension step. Touch-down PCR (Don et al., 1991) was used for PCR analysis. The annealing temperature for the initial cycle was $65^{\circ} \mathrm{C}$, which was then decreased by $1{ }^{\circ} \mathrm{C} /$ cycle for the following nine cycles. After the 10th cycle, the annealing temperature was fixed at $55^{\circ} \mathrm{C}$. PCR products were electrophoresed using an ABI 310 Genetic Analyzer (Perkin-Elmer, Applied Biosystems, USA). The lengths of PCR products were determined using GeneScan and Genotyper software (Perkin-Elmer, Applied Biosystems, USA) and interpreted to the alleles. 
Table 2. Details of 12 microsatellite markers used in our study

\begin{tabular}{|c|c|c|c|c|}
\hline No & Marker & Primer sequences ( $\left.5^{\prime}-3^{\prime}\right)$ & Repeat motif & $\begin{array}{c}\mathrm{MgCl}_{2} \\
\text { concentration }\end{array}$ \\
\hline 1 & Am 014 & $\begin{array}{l}\text { GTA CTA ACG TTG CTA TAT GAG } \\
\text { AAA GG } \\
\text { CTG GTT GTT CGC TTA TAT GG }\end{array}$ & $\begin{array}{l}(\mathrm{ATAC})_{3}(\mathrm{AC})_{26}(\mathrm{AT})_{3} \\
(\mathrm{GTAT})_{2}(\mathrm{AT})_{3} \mathrm{AC}\end{array}$ & $2.5 \mathrm{mM}$ \\
\hline 2 & Am 041 & $\begin{array}{l}\text { TAG GCT AAT GGT CAT ATT CCT } \\
\text { AG } \\
\text { AGA GAT AGG GGT ACA CAC TAA } \\
\text { AAA AAC }\end{array}$ & $(\mathrm{GT})_{36}$ & $\begin{array}{l}3.0 \mathrm{mM}+1 \% \\
\text { formamide }\end{array}$ \\
\hline 3 & Am 136 & $\begin{array}{l}\text { CCC ATT GCC GTT TCT TTG } \\
\text { GCA TTT CCC TTG GAA CAG TC }\end{array}$ & $(\mathrm{CT})_{20}$ & $\begin{array}{l}3.0 \mathrm{mM}+1 \% \\
\text { formamide }\end{array}$ \\
\hline 4 & Am 326 & $\begin{array}{l}\text { GGA CCA AAC TTA TGC AAC ACC } \\
\text { GCA TCA ATG TAC TAA ACC ATT } \\
\text { TCC }\end{array}$ & $(\mathrm{CA})_{20}$ & $2.5 \mathrm{mM}$ \\
\hline 5 & Am 341 & $\begin{array}{l}\text { CCA TTC GAG CAT CCT AAG AG } \\
\text { CGT ATG GCT GAG CTA CTT AAT } \\
\text { CA }\end{array}$ & $(\mathrm{CA})_{12}(\mathrm{TA})_{2}$ & $1.5 \mathrm{mM}$ \\
\hline 6 & Am 387 & $\begin{array}{l}\text { TGA TAC AAG GGA AGA CAG AGT } \\
\text { GG } \\
\text { CCA АCT CAA AAC CTG ACA ACG }\end{array}$ & $(\mathrm{AT})_{2}(\mathrm{GT})_{2}(\mathrm{AT})_{2}(\mathrm{GT})_{17}-(\mathrm{TA})_{8}$ & $1.5 \mathrm{mM}$ \\
\hline 7 & Am 429 & $\begin{array}{l}\text { CCT TCT TCT CTC ATC TAC CAA ACC } \\
\text { CCC ACA TCA TCA CTC ACA ACT }\end{array}$ & $(\mathrm{GT})_{16}$ & $1.5 \mathrm{mM}$ \\
\hline 8 & Am 435 & $\begin{array}{l}\text { ACC CTT TAT TTC TCA CAC GGA } \\
\text { ACA GAA GAA GAT GCA AAG AAG } \\
\text { G }\end{array}$ & $(\mathrm{CT})_{5}, \mathrm{CC}(\mathrm{CT})_{2}(\mathrm{CA})_{9}(\mathrm{CACT})_{3}$ & $2.5 \mathrm{mM}$ \\
\hline 9 & Am 436 & $\begin{array}{l}\text { ATG GAT CTT GTC CTT ATC TTG A } \\
\text { GGG CCA ATT TGA GTT TGG AA }\end{array}$ & $(\mathrm{TG})_{14,}, \mathrm{~T}$ & $2.5 \mathrm{mM}$ \\
\hline 10 & Am 460 & $\begin{array}{l}\text { CAC TAA TTG CTC ACA CAT TCC A } \\
\text { ATT CAT AGC CTC TCC CTT CAG }\end{array}$ & $(\mathrm{AT})_{4},(\mathrm{GT})_{12},(\mathrm{GGAAT})_{2},(\mathrm{GT})_{2}$ & $1.5 \mathrm{mM}$ \\
\hline 11 & Am 465 & $\begin{array}{l}\text { TGG GTA TCA CTT CCA CCA TT } \\
\text { AGG CTG CTT CTT TGT GCA GG }\end{array}$ & $(\mathrm{AC})_{23}$ & $\begin{array}{l}3.0 \mathrm{mM}+1 \% \\
\text { formamide }\end{array}$ \\
\hline 12 & Am 503 & $\begin{array}{l}\text { GTA TGA GTT CCA GTC CTA CCA } \\
\text { TCA } \\
\text { CAG TCC GGT TTT TGC TGT CA }\end{array}$ & $(\mathrm{TG})_{13},(\mathrm{TG})_{8}$ & $1.5 \mathrm{mM}$ \\
\hline
\end{tabular}

\section{Data Analysis}

The level of genetic diversity and parentage analysis of the two $A$. mangium SSOs of was calculated using Cervus 3.0 that was developed by Marshall et al. (1998) and revised by Kalinowski et al. (2007). The expected heterozygosity in the software was calculated using an unbiased formula from allele frequencies assuming HardyWeinberg equilibrium (Nei, 1987), whereas PIC that measure of informativeness related to expected heterozygosity and likewise was calculated from allele frequencies (Botstein et al., 1980; Hearne et al., 1992). The candidate male parent as pollen donor of each offspring was determined after following some steps of parentage analyis on Cervus 3.0 software. The dispersal of pollen donor from mother tree was then drawn in a map of each orchard and their distance was manually calculated. The process of drawing the position of male parent in the map and the prediction of their distance was simplify by the use of a map that was developed using a program for making an experimental design of family plots on SSOs, Design.exe (Kawasaki et al., 2000).

\section{RESULT AND DISCUSSION}

\section{A. Genetic Diversity}

The twelve microsatellite markers in A mangium was highly variable. AM004 Group D from South Sumatra has higher number of alleles than AM006 Group C from South Kalimantan. The number of alleles $(A)$ varied from 4-21 alleles per locus with an average 8.75 alleles in AM004 Group D and 7.67 alleles in average with $A=3-17$ alleles per locus in AM006 Group C from South 
Kalimantan) (Table 3). The observed heterozygosity $\left(H_{\mathrm{o}}\right)$ in both orchards was lower than its expected heterozygosity $\left(H_{\mathrm{e}}\right)$. The level of genetic diversity in both orchards was higher than found in planted stand of Acacia saligna subsp. saligna (Millar et al., 2008). The both orchards established using the similar provenances (Australia) so they have relatively similar level of genetic diversity $\left(H_{\mathrm{e}}=0.610\right.$ in AM004 Group D and $H_{\mathrm{e}}=0.606$ in AM006 Group C).

In general, high polymorphic information content (PIC) (0.554 in AM006 Group C and 0.0552 in AM004 Group D in average) was found in both orchards. The PIC varied from 0.267 to 0.710 and 0.357 to 0.783 in AM006 Group C South Kalimantan and AM004 Group D South Sumatra, respectively. The lowest and the highest
PIC was occured in primer Am341and Am041. (Table 3). Frequency of null alleles $( \pm 0.051$ in average) was low in both orchards (Table 3). The negative value of null allele that mean an excess of observed heterozygote genotypes was found for primer Am435 in AM006 Group C South Kalimantan. Further analysis revealed $14,87 \%$ and $15.16 \%$ of an excess of homozygotes for primer Am460 in AM006 Group C and AM004 Group D, respectively. A locus with a large positive estimate of null allele frequency does not necessarily imply that a null allele is present, however, it usually shows a characteristic pattern of repeated homozygotehomozygote mismatches in known parentoffspring relationship (http://www.fieldgenetics. com).

Table 3. Utility of 12 microsatellite loci for two SSOs of $A$. mangium

\begin{tabular}{lccccc}
\hline Locus & $A$ & $H_{\mathrm{o}}$ & $H_{\mathrm{e}}$ & PIC & Null \\
\hline AM006 Group C South Kalimantan & & & & \\
Am014 & 11 & 0.590 & 0.694 & 0.665 & 0.0830 \\
Am041 & 17 & 0.662 & 0.732 & 0.710 & 0.0473 \\
Am136 & 7 & 0.660 & 0.726 & 0.677 & 0.0500 \\
Am326 & 11 & 0.511 & 0.543 & 0.519 & 0.0291 \\
Am341 & 3 & 0.300 & 0.316 & 0.267 & 0.0251 \\
Am387 & 7 & 0.552 & 0.648 & 0.578 & 0.0798 \\
Am429 & 9 & 0.643 & 0.671 & 0.615 & 0.0207 \\
Am435 & 6 & 0.682 & 0.654 & 0.599 & -0.0172 \\
Am436 & 6 & 0.458 & 0.501 & 0.427 & 0.0433 \\
Am460 & 6 & 0.544 & 0.731 & 0.694 & 0.1487 \\
Am465 & 4 & 0.475 & 0.517 & 0.406 & 0.0420 \\
Am503 & 5 & 0.470 & 0.538 & 0.489 & 0.0666 \\
All loci & 7.67 & 0.546 & 0.606 & 0.554 & 0.0515 \\
\hline AM004 Group D South Sumatra & & & & \\
Am014 & 21 & 0.597 & 0.672 & 0.643 & 0.0518 \\
Am041 & 15 & 0.684 & 0.803 & 0.783 & 0.0777 \\
Am136 & 7 & 0.613 & 0.671 & 0.628 & 0.0391 \\
Am326 & 10 & 0.457 & 0.495 & 0.461 & 0.0373 \\
Am341 & 4 & 0.405 & 0.461 & 0.357 & 0.0632 \\
Am387 & 11 & 0.583 & 0.626 & 0.567 & 0.0315 \\
Am429 & 10 & 0.621 & 0.670 & 0.617 & 0.0379 \\
Am435 & 6 & 0.594 & 0.606 & 0.563 & 0.0119 \\
Am436 & 4 & 0.426 & 0.490 & 0.413 & 0.0719 \\
Am460 & 6 & 0.524 & 0.711 & 0.666 & 0.1516 \\
Am465 & 6 & 0.509 & 0.535 & 0.425 & 0.0217 \\
Am503 & 5 & 0.577 & 0.585 & 0.499 & 0.0061 \\
All loci & 8.75 & 0.549 & 0.610 & 0.552 & 0.0501 \\
\hline Rsts & & & & \\
\hline
\end{tabular}

Results are presented for parental and progeny cohorts combined. $A=$ Number of alleles, $H_{\mathrm{o}}=$ observed heterozygosity, $H_{\mathrm{c}}=$ expected heterozygosity, $\mathrm{PIC}=$ polymorphic information content, Null=estimated frequency of null alleles. A negative number denotes an excess of observed heterozygotes 


\section{B. Pollen Dispersal}

Twelve microsatellite markers were sufficient to establish the genotype of all trees in each SSO; however the success ratio for establishing seed genotype was variable. For the 20 seeds from each mother tree, 18-19 seeds in a total of 188 seeds in AM006 group C(South Kalimantan) and 19-20 seeds in a total of 192 seeds in AM004 group D (South Sumatra) were identified to genotype (data not shown); 112 seeds in AM006 and 142 seeds in AM004 were matched with their mother-tree genotype. Mismatching between mother tree and seeds was detected in 77 seeds in AM006, and 50 seeds in AM004. Detection power in AM006 was 32 seeds with a frequency of $28.8 \%$ and in AM004 was 60 seeds with a frequency of $42.3 \%$.

Pollen dispersal is a major component of gene flow in plant populations (Austerlitz et al., 2004; Robledo-Arnuncio and Gil, 2005). Pollen donors can dispersed randomly around mother tree and crossing could be occured from all direction (Figure 1), the similar trend that was found in bur oak, Quercus macrocarpa (Dow and Ashley, 1996) and a planted stand of $A$. saligna subsp. saligna (Millar et al., 2008).

A.

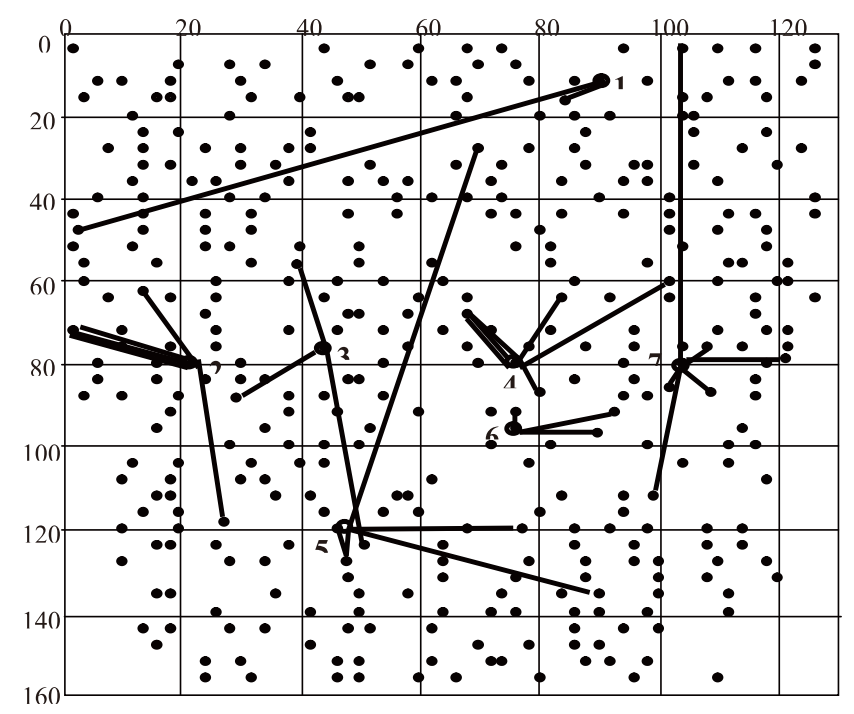

B.

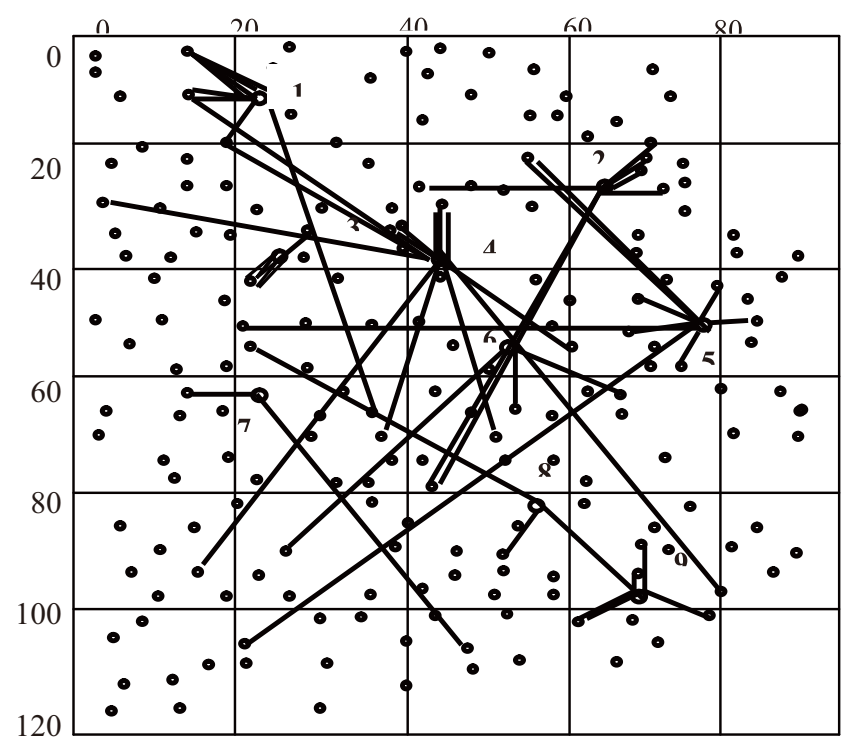

Figure 1. Pollen dispersal in AM004 Group D (South Sumatra) SSO (A) and AM006 Group C (South Kalimantan) SSO (B). The selected trees are indicated with small circles. The mother trees were indicated with large circles. Pollen dispersal is indicated with lines 
Pattern of pollen dispersal in both SSOs of $A$. mangium was random, however, we also found multiple paternity/correlated outcrossing wherein some of the detected paternal trees were to be the pollen donor of several seeds (Table 4). It was 3 trees $(9.4 \%)$ that were pollen donors of 8 seeds $(25 \%)$ in South Kalimantan, whereas in South Sumatra, there were nine trees (15\% of all detected paternal trees) as pollen donor of 27 seeds ( $45 \%$ of all pollen donors). Contribution of pollen from neighboring trees was high; 7 trees $(21.8 \%)$ in AM006 and 16 trees $(26.7 \%)$ in AM004 (Table 4). They were pollen donors of nine seeds $(28.1 \%$ from all pollen donors) in
South Kalimantan and 29 seeds with frequency 48.3 \% from all pollen donors in South Sumatra. The correlated mating (George et al., 2008; Coantes et al., 2006; Millar et al., 2008) was more likely to be due to nature of Acacia floral biology (George et al., 2008; Millar et al., 2008). Pollen in Acacia is presented in the form of polyads (fused pollen grains), so all insects that forage for polyads will have immediate access to respective stigmas (Coantes et al., 2006). In $A$. saligna, the flowers are grouped into complex inflorescences, and pollen from the same paternal tree may regularly fertilize more than one flower within a cluster (Millar et al., 2008). Pollinator will concentrate on more

Table 4.Pollen donors in AM006 group C (South Kalimantan) SSO (A) and AM004 group D (South Sumatera) SSO (B)

\begin{tabular}{|c|c|c|c|c|c|c|c|}
\hline \multirow[t]{2}{*}{ No } & \multirow[t]{2}{*}{ Mother Tree ID } & \multirow{2}{*}{$\begin{array}{c}N \text { pollen } \\
\text { donor }\end{array}$} & \multicolumn{2}{|c|}{ Multi contributions ${ }^{1}$} & \multicolumn{2}{|c|}{ N Neighbor ${ }^{2}$} & \multirow[t]{2}{*}{ Self } \\
\hline & & & Tree ID & N. seed & Tree ID & N.seed & \\
\hline \multicolumn{7}{|c|}{ A. AM006 group C (South Kalimantan) SSO } & \multirow[b]{2}{*}{0} \\
\hline 1. & AM006 03/45 & 6 & AM006 03/12 & 3 & AM006 03/68 & 1 & \\
\hline 2. & AM006 04/47 & 5 & AM006 04/67 & 2 & AM006 04/67 & 2 & 0 \\
\hline \multirow[t]{3}{*}{3} & AM006 03/47 & 8 & - & - & AM006 03/36 & 2 & 0 \\
\hline & & & & & AM006 03/71 & 1 & \\
\hline & & & & & AM006 03/59 & 1 & \\
\hline 4 & AM006 03/29 & 3 & - & - & - & & 0 \\
\hline 5 & AM006 04/02 & 3 & - & - & AM006 03/78 & 1 & 0 \\
\hline 6 & AM006 03/41 & 5 & AM006 03/14 & 3 & - & & 0 \\
\hline \multirow[t]{2}{*}{7} & AM006 01/28 & 2 & - & - & AM006 01/41 & 1 & 0 \\
\hline & Total & 32 & $3(9.4 \%)$ & $\begin{array}{c}8 \\
(25 \%)\end{array}$ & $7(21.8 \%)$ & $9(28.1 \%)$ & 0 \\
\hline
\end{tabular}

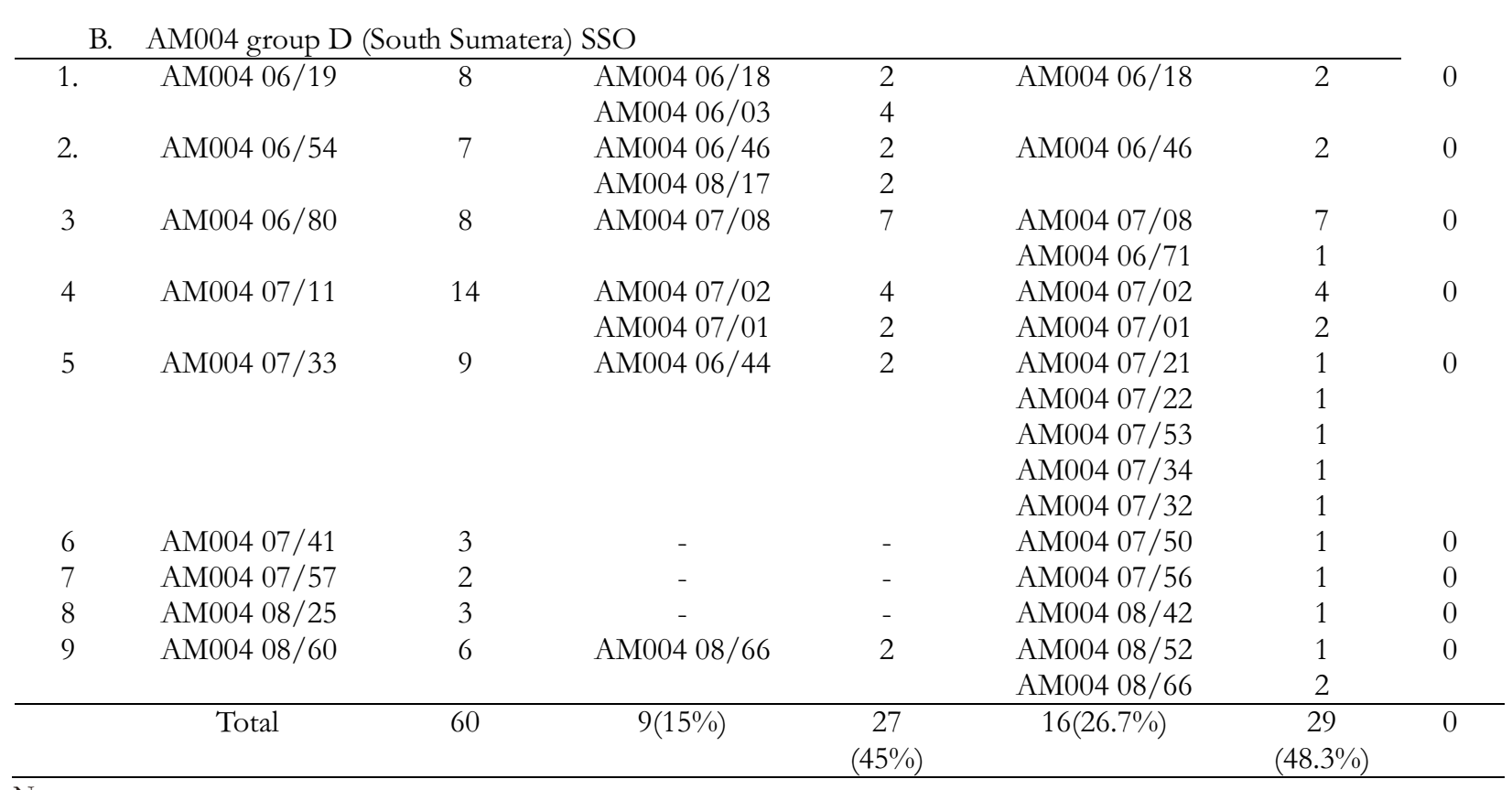

Note:

${ }^{1}$ Multi contributions of trees that were male parents;

${ }^{2}$ The number $(N)$ of male parents adjacent to the mother tree producing seeds 
rewarding patches, and when pollinators visit more rewarding patches, they will travel less far to the next flower or plant (Richards, 1997). Flowering time will also influence the trend. Butcher (2002) found no evidence of selfing in location where the majority of trees flowered synchronously and seed orchard established from the same source population. Selfing should be avoided because it usually performs negative effect and inbreeding depression. Study on effect of inbreeding on $A$. mangium found that selffertilized individuals were significantly $(\mathrm{P}<0.001)$ slower-growing than were outcrossed individuals (Harwood et al., 2004).

The most frequent pollination distance between mother tree and male parent was $0-10 \mathrm{~m}$ in both SSOs; distances of 10-20 m, 20-30 m and $30-40 \mathrm{~m}$ were associated with a lower frequency of pollination. In the AM006, the number of crosses was $28.1 \%, 25 \%, 15 \%$ and $9.4 \%$ at $0-10$ $\mathrm{m}, 10-20 \mathrm{~m}, 20-30 \mathrm{~m}$ and $30-40 \mathrm{~m}$ distance, respectively. In AM004, the trend was similar but most of the crossing was in $0-10 \mathrm{~m}$ range; the other ranges showed very low frequency (Figure 2). The pollinator movement might have contributed to these patterns. The bee genus Trigona are the most numerous insect visitors to $A$. mangium flowers and had the highest numbers of polyads on their hairy bodies (Sedgley et al., 1991). For bee-pollinated plants, it is usual to find at least $80 \%$ of flights are less than $1 \mathrm{~m}$ in distance, and $99 \%$ are less than $5 \mathrm{~m}$, though the nature of pollinator behaviour that occasional grains may travel much further (Richards, 1997).
Furthermore, travel will be much shorter in areas of high plant density such as in AM004 group D (established in 0.96 ha area with 251 trees) than in AM006 Group C that has lower density (190 trees $\mathrm{ha}^{-1}$ ). As explained in Richards (1997), in sparsely populated areas, pollen travel will, by definition, be more distant,however, the number of plants which the pollen may reach may be no greater than in dense populations, and indeed may well be less. Sparse area of dense population will also receive far fewer pollinator visits, as these areas will form patches of low reward, and thi will minimize gene travel in these areas (Richards, 1997).

Study in Acacia sp. showed that most of Acacias are outcrossing species. It was found in $A$. nilotica ssp. kraussiana (Mandal and Ennos, 1995), $A$. saligna subsp. saligna (Millar et al., 2008), mixed mating with preferential outcrossing in $A$. saligna (George et al., 2006) and high levels of outcrossing with little variation in the outcrossing rate between populations in $A$. auriculiformis and $A$. crassicarpa (Moran et al., 1989b). Our study suggest a possible of mixed mating with predominantly outcrossing in $A$. mangium. It was supported by our data that found no self-pollinated seed (Table 4), the presence of multiple paternity/correlated outcrossing (Table 4) and high crossing in close area (Figure 2) with neighbour trees (Table 4). Previous $A$. mangium study showed that this species has flexible mating system with its outcrossing rates in natural populations range from complete selfing in outlying populations with low genetic diversity to complete outcrossing in the

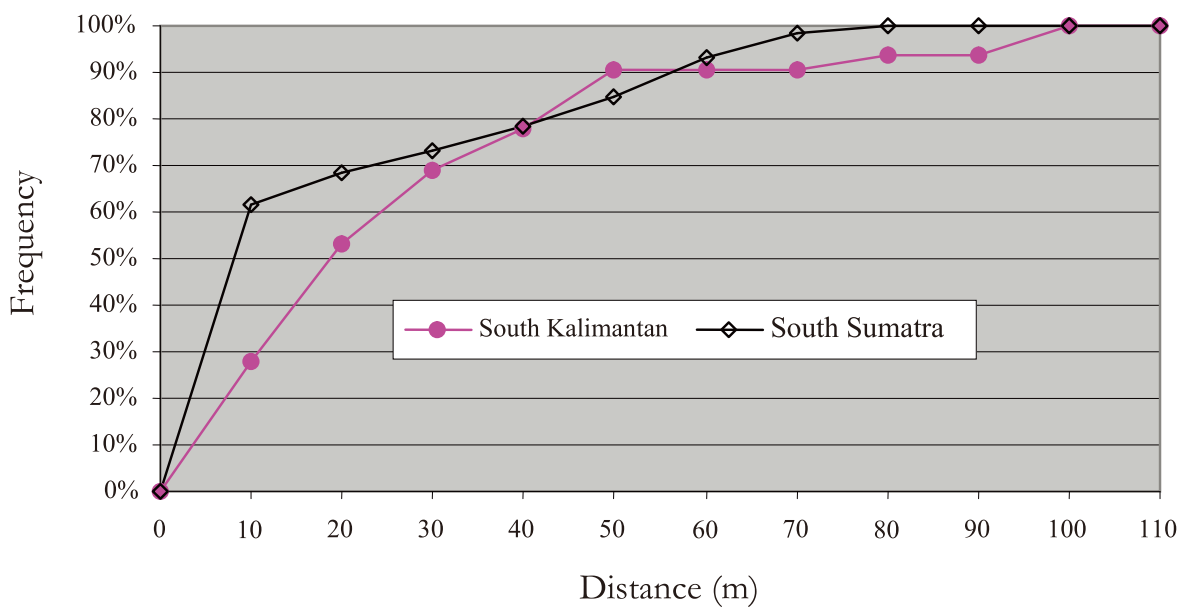

Figure 2. The cumulative frequency of pollen dispersal distance in the AM006 group C (South Kalimantan) and AM004 group D (South Sumatra) SSO 
more variable New Guinea populations (Butcher et al., 2004). The trend of mating with their nearest neighbours can result in significant inbreeding. Computer simulations study of nearest-neighbor pollination in outcrossing plant species found that this restricted gene flow caused inbreeding, a rapid increase in homozygosity, and striking microgeographic differentiation of the populations (Turner et al., 1982).

The design of an efficient tree breeding strategy will be greatly influenced by our knowledge and through understanding of the mating systems (Mandal and Ennos, 1995). Our analysis in $A$. mangium showed that about $80 \%$ of all crosses were found within 40-m distance range in both SSO (Figure 2). The similar result was also found in other studies in planted stand of $A$. saligna. The average pollen dispersal distance was $37 \mathrm{~m}$ with the majority of progeny sired by paternal trees within a 50-m neighborhood of the maternal tree (Millar et al., 2008). The both study using Acacia species in planted area such as seedling seed orchard will gives an impact for designing seed orchard, clonal seed orchard etc. The result can be applied for such as application of target trees in 40-m distance range in order to increase chances of mating between the expected trees.

Seeds within a pod are full sib relationship (Isoda et al., 2002) so the estimated haplotypes was searched from the genotype data of all the trees in the SSO. In most cases, only one tree will match to the estimated haplotype, however, there some haplotypes were not found in the SSO. This is happened because the pollen may come from trees outside the SSO. Studies showed that $62 \%$ in neo tropical tree (Latouche-Halle et al., 2004) and $66.1 \%$ in norway spruce (Piotti et al., 2009) of the pollen contributing to seed came from outside the study plot. Minimum isolation distance is needed to reduce pollen contamination from outside the SSO. Timyan (1999) predicted that a distance of up to $100 \mathrm{~m}$ should be sufficient to isolate the orchard from such sources of contamination. The orchards used in our study adopted a 100-200 m isolation distance to avoid pollen contamination (Nirsatmanto, pers. comm.). The isolation distance was expected can reduce pollen contamination, however, as our study still found male parent in the range of $100 \mathrm{~m}$ from mother tree and high mismatched in known parent and offspring so the possibilities of minimum isolation distance to reduce pollen contamination from outside the SSO could not be predicted. More studies using different distance as an isolation area in $A$. mangium is expected can resolve effective isolation distances in $A$. mangium to reduce pollen contamination from outside SSO.

\section{CONCLUSION}

The mating system study using 12 microsatellite markers found high outcrossing with low selfing evidence was found in both SSO. Pollen dispersed randomly among the trees in each SSO and mating mostly occurs in close distance. Application of all these aspects of mating systems found in this study such as random pollen dispersal and the effective pollen dispersal distance can be used for establishing seedling seed orchard, clonal seed orchard and in other tree improvement activities of $A$. mangium.

\section{ACKNOWLEDGEMENTS}

We would like to thank PT. Musi Hutan Persada in South Sumatra and PT. Inhutani III in South Kalimantan for supporting in samples collection. Special thank go to Chris Beadle for his valuable comments on the manuscript. This work was part of the Forest Tree Improvement Project Phase II collaborated between the Government of Indonesia and Japan International Cooperation Agency (JICA) Japan.

\section{REFERENCES}

Austerlitz, F., Dick, C. W., Dutech, C., Klein, E. K., Oddou-Muratorio, S., Smouse, P. E., et al. (2004). Using genetic markers to estimate the pollen dispersal curve. Molecular Ecology, 13, 937-954.

Botstein, D., White, R. L., Skolnick, M., \& Davis, R. W. (1980). Construction of a genetic linkage map in man using restriction fragment length polymorphism. American Journal of Human Genetics, 32, 314-331. 
Butcher, P. (2002). Molecular breeding of tropical trees. Proceeding of the International Conference on Advances in Genetic Improvement of Tropical Tree Species, 1-3 October 2002 Yogyakarta, Indonesia. Yogyakarta: Centre for Forest Biotechnology and Tree Improvement.

Butcher, P. A., Decroocq, S., Gray, Y., \& Moran, G. F. (2000). Development, inheritance and crossspecies amplification of microsatelite markers from Acacia mangium. Theor Appl Genet, 101, 1282-1290.

Butcher, P., Harwood, C., \& Quang, T. H. (2004). Studies of mating systems in seed stands suggest possible causes of variable outcrossing rates in natural populations of Acacia mangium. Forest Genetics, 11(3-4), 303-309.

Casiva, P. V., Vilardi, J. C., Cialdella, A. M., \& Saidman, B. O. (2004). Mating system and population structure of Acacia aroma and $A$. macracantha (Fabaceae). American Journal of Botany, 91(1), 5864.

Coantes, D. J., Tischler, G., \& McComb, J. A. (2006). Genetic variation and the mating system in the rare Acacia sciophanes compared with its common sister species Acacia anfractuosa (Mimosaceae). Conservation Genetics, 7, 931-944.

Don, R. H., Cox, P. T., Wainwright, B. J., Baker, K., \& Mattick, J. S. (1991). 'Touchdown' PCR to circumvent spurious priming during gene amplification. Nucleic Acids Research, 19, 4008.

Dow, B. D., \& Ashley, M. V. (1991). Microsatellite analysis of seed dispersal and parentage of saplings in bur oak, Quercus macrocarpa. Molecular Ecology, 5, 615-627.

George, N., Byrne, M., \& Yan, G. (2008). Mixed mating with preferential outcrossing in Acacia saligna (Labill.) H. Wendl. (Leguminosae: Mimosoidae). Silvae Genetica, 53(3), 139-145.

Glaubitz, J. C., \& Moran, G. F. (2000). Genetic tools: the use of biochemical and molecular markers. In A. Young, D. Boshier , \& T. Boy 1 e (Eds.), Forest Conservation Genetics, Principles and Practice. Australia: CSIRO Publishing.

Hancock, J. M. (1999). Microsatellite and Other Simple Sequences: Genomic Context and Mutational Mechanisms. In D. B. Goldstein, \& C. Schlotterres (Eds.), Microsatellites, Evolution and Appllications. New York: Oxford University Press.

Harwood, C. E., Thinh, H. H., Quang, T. H., Butcher, P. A., \& Williams, E. R. (2004). The effect of inbreeding in early growth of Acacia mangium in Vietnam. Silvae Genetica, 53(2), 65-69.

Hasegawa, Y., Suyama, Y., \& Sewa, K. (2009). Pollen donor composition during the early phases of reproduction revealed by DNA genotyping of pollen grains and seeds of Castanea crenata. New Phytologist, 182, 994-1002.

Hashimoto, K., Kurinobu, S., \& Suhendi, H. (1996). Establishment of seed sources of tropical tree species in Indonesia. Proceeding of the QFRIIUFRO Conference, Caloundra, Australia, (pp. 370371).

Hearne, C. M., Ghosh, S., \& Todd, J. A. (1992). Microsatellites for linkage analysis of genetic traits. Trends in Ecology and Evolution, 8, 288-294.

Isoda, K., Yuskianti, V., \& Rimbawanto, A. (n.d.). Verification of full-sib relationship of seeds within a pod of Acacia mangium sing parentage analysis by microsatellite markers . Proceeding of the International Conference on Advances in Genetic Improvement of Tropical Tree Species, 1-3 October 2002. Yogyakarta, Indonesia. Yogyakarta: Centre for Forest Biotechnology and Tree Improvement.

Kalinowski, S. T., Taper, M. L., \& Marshall, T. C. (2007). Revising how the computer program cervus accomodates genotyping error increases success in paternity assignment. Molecular Ecology, 16, 1099-1106.

Kawasaki, H., Kurinobu, S., \& Leksono, B. (2000). Manual of the "Design.exe" for making an experimental design of family plots on seedling seed orchards. FTIP-P2-No.17. Yogyakarta.

Kurinobu, S., Nirsatmanto, A., \& Susanto, M. (1994a). General information of seed source stablishment of Acacia mangium in South Kalimantan (Fiscal year 1993/1994). FTIP No. 22. Yogyakarta.

Kurinobu, S., Nirsatmanto, A., \& Susanto, M. (1994b). General information of seed source stablishment of Acacia mangium in South Sumatra (Fiscal year 1993/1994). FTIP No.23. Yogyakarta.

Latouche-Halle, C., Ramboer, A., Bandou, E., Caron, H., \& Kremer, A. (2004). Long distance pollen flow and tolerance to selfing in a neotropical tree species. Molecular Ecology, 13, 1055-1064.

Mandal, A. K., \& Ennos, R. A. (1995). Mating system analysis in a natural population of Acacia nilotica subspecies kraussiana. Forest Ecology and Management, 79, 235-240.

Marshall, T. C., Slate, J., Kruuk, L. E. B., \& Pemberton, 
J. M. (1998). Statistical confidence for likelihood-based paternity inference in natural populations. Molecular Ecology, 7, 639-655.

Millar, M. A., Byrne, M., Nuberg, I., \& Sedgley, M. (2008). High outcrossing and random pollen dispersal in a planted stand of Acacia saligna subsp. saligna revealed by paternity analysis using microsatellites. ree genetics \& Genomes, 4, 367-377.

Moran, G. F., Muona, O., \& Bell, J. C. (1989). Acacia mangium: a tropical forest tree of the oastal lowlands with low genetic diversity. Evolution, 43(1), 231-235.

Moran, G., Muona, O., \& Bell, J. C. (1989). Breeding systems and genetic diversity in Acacia auriculiformis and A. crassicarpa. Biotropica, 21(3), 250-256.

Nei, M. (1987). Molecular evolutionary genetics. New York: Columbia University Press.

Nirsatmanto, A. (2005). Study on statistical genetic analysis, and the application to the reeding in Acacia mangium (Doctoral Thesis). Japan: Kyushu University.

Piotti, A., Leonardi, S., Piovani, P., Scalfi, M., \& Menozzi, P. (2009). Spruce colonization at treeline: where do those seeds come from? Heredity, 103, 136-145.

Richards, A. J. (1997). Plant Breeding Systems (2 ${ }^{\text {nd }}$ ed.). London: Chapman \& Hall.

Robledo-Arnuncio, J. J., \& Gil, L. (2005). Pattern of pollen dispersal in a small population of Pinus sylvestris L. revealed by total-exclusion paternity analysis. Heredity, 94, 13-22.

Sedgley, M., Khen, C. V., Smith , R. M., \& Harbard, J. (1991). Insect visitors to flowering branches of Acacia mangium and Acacia auriculiformis. In L. T. Carron, \& K. M. Aken (Ed.), Breeding Technologies for Tropical Acacias. ACLAR Proceedings No. 37. Canberra.

Shiraishi, S., \& Watanabe, A. (1995). dentification of chloroplast genome between Pinus densiflora Sieb. et Zucc. and P. thunbergii Parl. based on the polymorphism in rbcL gene. Journal of the Japanese Forestry Society, 77(5), 429-436.

Tabbener , H. E., \& Cottrell, J. E. (2003). The use of PCR based DNA markers to study the paternty of poplar seedlings. Forest Ecology and Management, 179, 363-379.
Timyan, J. C. (1999). Management plan for improved tree seed production from orchards and progeny/provenance trials in Haiti. Port-au-prince, Haiti: Pan American Development Foundation/PLUS Project 27.

Turner, M. E., Stephens, J. C., \& Anderson, W. W. (1982.). Homozygosity and patch structure in plant populations as a result of nearest neighbor pollination. Proc. Natl. Acad. Sci, 79 , 203-207. 
